\title{
CITRUS FARMERS PRODUCTION CONSTRAINTS AND ATTITUDE TO TRAINING ON IMPROVED TECHNIQUES OF CITRUS PRODUCTION
}

\author{
OYEDELE, ${ }^{1}$ O. O. AND M. K. YAHAYA ${ }^{2}$ \\ ${ }^{1}$ Department of Farming Systems and Extension, \\ National Horticultural Research Institute, Idi - Ishin, Ibadan, Nigeria. \\ ${ }^{2}$ Department of Agricultural Extension and Rural Development, \\ University of Ibadan, Ibadan, Nigeria.
}

\section{Corresponding author; toyink2@yahoo.com, 234-8033536383}

\begin{abstract}
Emerging trends and advances in the citrus industry globally necessitates updating farmers knowledge and skill base to cope profitably in the industry. Therefore, this study was designed to assess the disposition of farmers to training on improved techniques of citrus production and also examine production constraints confronting them. Randomly selected 321 citrus farmers from Oyo, Ondo, Osun and Ekiti states were assessed through the use of pretested interview schedule. Data generated were analysed through frequency counts, percentages, and means. Results showed that $74.7 \%$ and $60.5 \%$ of farmers in Ekiti and Osun states had a favourable attitude to training. Four topmost constraints limiting production are: pest problem > low yielding trees> premature fruit drop > lack of capital. Farmers should be trained in integrated pest management techniques for citrus to handle pest issues, and also encouraged to plant improved budded citrus seedlings which are high yielding. Reduction of bureaucratic procedures involved in accessing special government agricultural loans should be minimized to assist the farmers address capital constraint. Capacity of farmers favourably disposed towards training should be strengthened through organized training programmes.
\end{abstract}

Key words : Improved technology, Citrus, Training, Attitude

\section{INTRODUCTION}

Citrus is a fruit listed as being of high priority and has been identified as one of the most cultivated fruit crop in Southwestern Nigeria. Internationally it ranks within the top three cultivated fruit crops. Citrus and citrus products are rich in vitamins, minerals and dietary fiber which are essential for normal growth and development and overall nutritional well being (Economos and Clay, 1999, Aubert and Vullin, 1998 ). Locally too, it is a high ranking fruit tree crop which has made the only horticultural research institute in sub-Saharan Africa to devote a whole programme for its research and development. In order of importance citrus is ranked first among other fruit crops by farmers (NIHORT, 2000). As at 2007, Nigeria ranked $9^{\text {th }}$ in world citrus production with 3,325,000 tonnes. (FAO, 2007)

Training can be regarded as any planned or organized effort that is specifically designed to help individuals develop increasing capabilities. It is also the process of transmitting and receiving information related to problem solving.( Ojiambo, 1992) Youdeowei and Kwarteng (1995)described training as the process of providing knowledge and skill and bring about desired changes in attitudes in order to improve the competence of the people being trained. Training is an organized effort at behaviour change, entailing a skillful management of both human and physical resources to facilitate the desired change ( International Rice Research Institute,1990). Farmers in the past have not had positive attitude to training because it had not been socially and economically feasible. A major challenge in the development and 
effective maximization of the potential of the agricultural sector which can help eradicate poverty has been adduced to lack of training for farmers. (Owoeye, 2010)

Attitudes can be defined generally as a relatively constant, hardly changeable, fundamental dispositions of a person which are built up through interaction with one's environment .They are fundamental driving force for human actions and very important for the understanding and prognosis of individual decision and behaviour patterns (Altmann,1983). Attitude describes a person's enduring favorable or unfavorable cognitive evaluations, feeling and action tendencies toward some object or idea.An individual's attitude settle into a coherent pattern, and to change one may require difficult adjustment in many others, thus signifying its importance (Adegbola, 2008)

Improved technologies generated and developed by research organizations are meant to bring about substantial increase in agricultural productivity and farmers income Ogungbile and Olukosi(1989) .Some of the improved technologies already developed for citrus production include: correct plant density for optimum citrus yield, improved nursery techniques reducing period of budded seedling from 24 months to 12 months. Others are seed coat removal and scarification for accelerated rootstock seed germinating, intercropping models of citrus, production of bottled citrus juice, jams and marmalades. Although a lot of work has been done in development of improved technologies for citrus production,little has been done to find out the attitude of farmers towards being trained on the use of these generated technologies to achieve optimum productivity.A major challenge in the development and effective maximization of the potential of the agricultural sector has been adduced to lack of training for farmers who are major players in the sector,thus resulting in reduction of investment opportunities for the country. Also, there has been an increasing awareness of constraints in horticultural crop production and utilization because horticultural crops are highly perishable.Though past studies has generalized constraints, constraints can be locality and crop specific. Thus the study assessed the attitude of citrus farmers towards training on improved techniques of citrus production, and also examined the production constraints affecting them.

\section{METHODOLOGY}

\section{Area of study}

The study covered four states in Sothwestern Nigeria which include Oyo, Osun, Ondo and Ekiti States of Nigeria. These states account for $60-70 \%$ of citrus production in southwestern Nigeria. Agriculture is the main source of livelihood of rural people in the zone with variations in crops grown among the States. The climate and vegetation supports commercial production of citrus. Ekiti State has tropical climate with two distinct seasons: rainy (April-October) and dry season (November-March). Temperature ranges between 21$28^{\circ} \mathrm{C}$ with high humidity.Tropical forest is prevalent in the Southern part of the State, and its luxuriant vegetation supports production of arable crops such as yam, cassava, rice and commercialisable quantities of fruit trees. (Adetola, 2008). In Oyo state, there are rainforest areas characterized by large tall crowned trees, and the high annual rainfall supports perennial trees cultivation. Similarly too in Ondo State, climate is of low land tropical rainforest type having distinct wet and dry seasons. Natural vegetation is the high forest which supports cultivation of tree crops such as cocoa, citrus, kola and oilpalm. Osun State's tropical climate favours the production of an array of arables such as rice, maize, cassava and tree crops such as citrus, plantain/banana, cocoa, kolanut and cashew (Nigeria, 2003).

\section{Study population, sampling procedure and sample size}

The population for study comprised of citrus farmers whose citrus farms were either in homestead, boundary or orchard forms. The four states employed for this study were 
purposively sampled because of their sizeable contribution to citrus production in the Southwestern zone. Within the States only fruit producing zones were selected. Following the ADP zoning system of sampling within zones, blocks and cells, multi - stage sampling technique and snowballing was used to obtain the population of 321 citrus farmers from Osun (76), Oyo (76), Ondo (90) and Ekiti (79) states.

\section{Measurement of variables and data analysis}

Attitudinal questions comprising of positive and negative statements were drawn up to ascertain the favorability of citrus farmers to training on improved techniques of citrus production. The scale used was based on Thurstone's Equal Appearing Interval method and consisted of 10 items. The negative and positive items were randomly placed in the scale to prevent respondents' bias. Rating of the attitudinal statements was done using a 5-point Likert scale of Strongly agree, Agree, Undecided, Disagree and Strongly disagree. Positive statements with the "strongly agree" option were scored 5, while negative statements were scored 1. Mean score and above were classified as favourable, while scores below the mean were classified as unfavourable. Also, farmers were asked to list production constraints affecting them, thereafter the constraints were ranked. Data generated through pre-tested interview schedule were analyzed with frequency counts, percentages, and means.

\section{RESULTS AND DISCUSSION}

\section{Attitude of citrus farmers to training}

Findings from results as shown on Table 2 revealed that majority of the farmers in Ekiti(74.7\%)and Osun (60.5\%)states were favorably disposed towards receiving training in improved techniques of citrus production. The attitude of a farmer towards training may affect his disposition to accepting improved technologies, Thus, if farmers who have favorable attitude are exposed to relevant training programmes in citrus production, they are likely to adopt improved technologies which can be used to enhance their production level and ultimately increase their income. Center for Rural Development and Training(CRDT,1993)also posit that attitudes are more important in the performance of any practical task. Attitude is basically psychological and mostly personal. Ensuring a change of farmers' attitude from indifference and negative to positive attitude requires an emerging need to educate farmers, mostly through training. (Ajayi, 2006). Training in fruit production is supposed to be continuous in nature and refresher courses to be organized for farmers to update their knowledge.Item analysis was done to further strengthen the attitude scale. Mean score for the ten items was 3.6. Scores above the mean showed that more than fifty percent of the items really discriminated.(Table 2). Item analysis is a procedure to increase the reliability and validity of a test by separately evaluating each item or statement to determine whether the item discriminates in the same way that the overall scale is intended to discriminate. Item analysis is important in analyzing each of the items for appropriateness and unambiguity.(Akinbile, 1999).

Table 1: Farmers' Attitudinal Score Towards Training in improved techniques of citrus production $(\mathbf{n}=\mathbf{3 2 1})$

\begin{tabular}{llcccc}
\hline Categories & Score & Ekiti(n=79) & Oyo(n=76) & \multicolumn{2}{c}{ Oocation } \\
Osun(n=76) & \multicolumn{2}{c}{ Ondo(n=90) } \\
\hline Favourable & $9-15$ & $31(40.8)$ & $46(60.5)$ & $32(35.6)$ & $59(74.7)$ \\
Unfavourable & $16-27$ & $45(59.2)$ & $30(39.5)$ & $58(64.4)$ & $20(25.3)$ \\
\hline Minimum Score & $=9.0 ;$ Maximum Score & $=27.0 ;$ Mean Score & $=16.0$
\end{tabular}


Journal of Agriculture and Social Research (JASR) VOL. 10, No. 2, 2010

Table 2: Item analysis of attitudinal statements $\quad(n=321)$

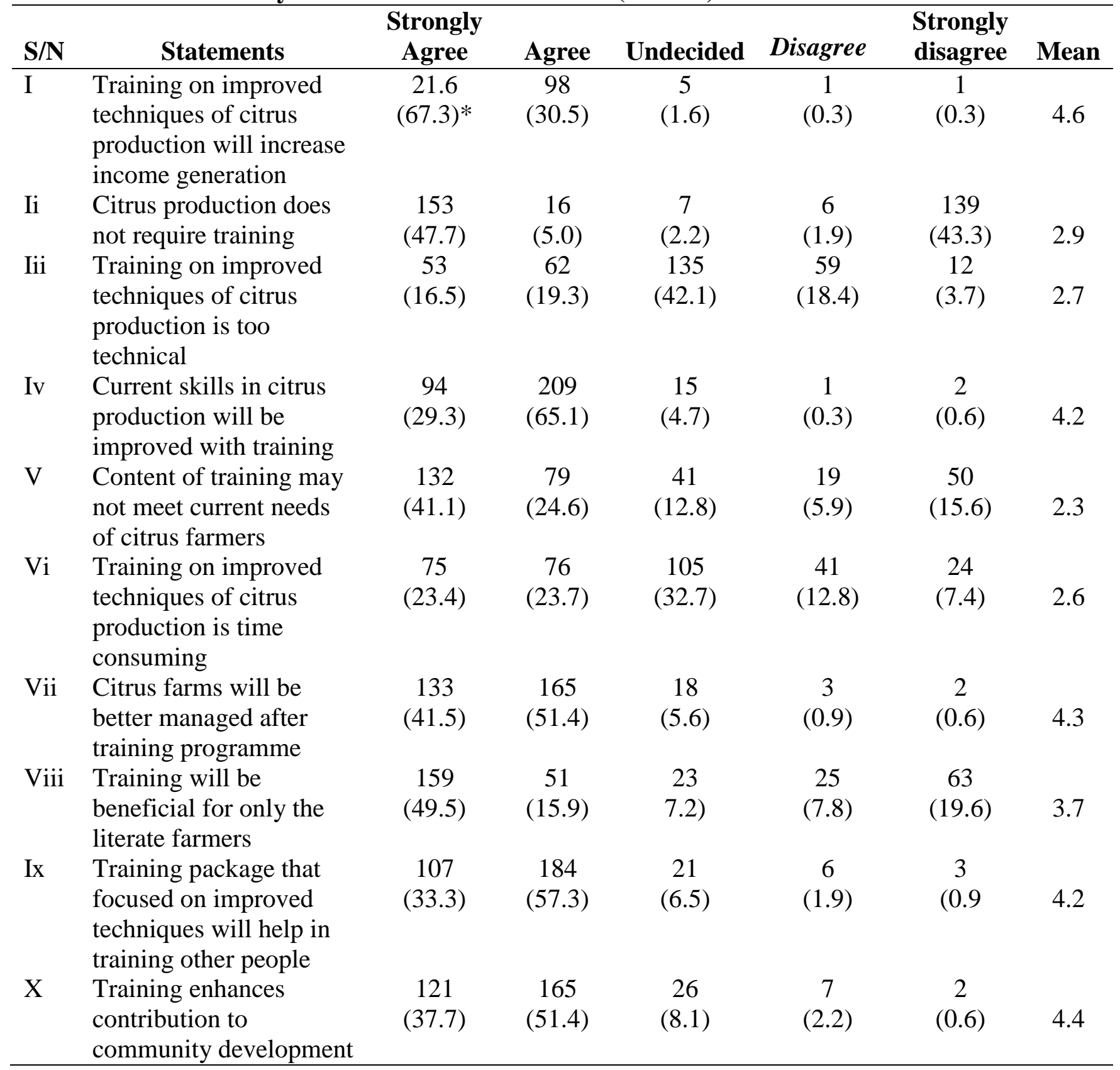

Mid point $=3.00$; Any mean score less than 3.00 suggests disagreement while any mean score greater than or equal to 3.00 suggests agreement

*Figures in parentheses are percentages

\section{Production constraints of citrus farmers}

Production constraints to citrus production identified by farmers include irregular fruit bearing pattern, fluctuating weather, inadequate farm labour. Out of all these constraints, pest problem was ranked most limiting by $87.5 \%$ of the respondents. Pest and diseases can affect yield of citrus trees, cause blemishes on fruits which reduces the market value and ultimately the monetary gain which should have accrued to the farmer.

Gwary and Nahunnaro, (2003) corroborates that pest and diseases problem are very important constraints to horticultural production in Nigeria. Similarly, Nigerian farmers are faced with the arduous task of producing horticultural crops which are pest, diseases and blemish free 
both for consumption and export (Gwary, 2008).Losses arising from pest and disease infestation on farmers' plots remain a major challenge to agricultural productivity and food security (NIHORT,2000).

Prevalence of low yielding trees as indicated by $84.7 \%$ of the farmers is another major constraint limiting citrus production. Majority of the farmers used unbudded seedlings to set up their farms, having a narrow genetic base. The economic returns which is supposed to translate into improved livelihood for the famer is also limiting because of the low yield. Fruit drop of citrus trees caused by fruit piercing insects is another limiting factor in production indicated by $84.4 \%$ of the farmers. The aborted fruits have no market value and amount to waste of resources expended on the maintenance of the citrus trees. In some instances, problems resulting from fruit drop can wipe off total fruits produced in an orchard. Umeh et al,(2008) reported higher fruit fly species diversity in the rainforest ecological zone of Nigeria, and also implicated some cultural practices of fruit farmers as contributing to its abundance and spread.

Lack of capital is also one of the limiting constraints identified by $78.8 \%$ of the farmers. Citrus is a perennial crop requiring constant management for continous productivity, and inadequate finance may hamper this aspect of production. Majority of the citrus farmers do not fall into the category of large scale farmers, making it impossible for them to source credit from formal sources due to high interest rates and lengthy administrative procedures. NIHORT (2008), NARSP (1997) reported that only 5\% of total volume of loans from formal sources go to small scale farmers with the greater part diverted to state agencies and few large scale farmers. Citrus farmers who view fluctuating weather as a constraint were $75.7 \%$. The importance of climate to crop production cannot be overemphasized and has been described as the most indispensable variable factor influencing agricultural production.Climate exerts great influence on various physiological growth stages of plants. (Afolayan et al, 2005). Climate extremes have been reported to dictate production trend of agricultural activities (IPCC, 1998). Also, marketable yield of many horticultural crops such as fruits, tomatoes display high sensitivity to climate change compared to grain and oilseeds crops. (Backlund et al, 2008). Rural dwellers in the tropics face greater risks of poor harvest, food security and other health related problems as a result of climate change. Farmers will require information about future changes in the climate to assist in good decision making and adjustment of their farming practices.

Table 3: Production constraints of citrus farmers $(n=321)$

\begin{tabular}{lccc}
\hline Type of constraint & \multicolumn{3}{c}{ Degree of production constraint } \\
& Nes & No & Ranking \\
\hline Fruit drop & $271(84.4)^{*}$ & $50(15.6)$ & $3^{\text {rd }}$ \\
Low yielding trees & $272(84.7)$ & $49(15.3)$ & $2^{\text {nd }}$ \\
Pest problem & $281(87.5)$ & $40(12.5)$ & $1^{\text {st }}$ \\
Mistletoe & $204(63.6)$ & $117(36.4)$ & $9^{\text {th }}$ \\
Lack of farmhands & $201(62.6)$ & $120(37.4)$ & $10^{\text {th }}$
\end{tabular}




\begin{tabular}{lccc}
\hline Lack of capital & $253(78.8)$ & $68(21.2)$ & $4^{\text {th }}$ \\
Fluctuating weather & $243(75.7)$ & $78(24.3)$ & $5^{\text {th }}$ \\
Fire outbreak & $169(52.6)$ & $152(47.4)$ & $11^{\text {th }}$ \\
$\begin{array}{l}\text { Irregular fruit bearing } \\
\text { Pattern }\end{array}$ & $233(72.6)$ & $88(27.4)$ & $6^{\text {th }}$ \\
$\begin{array}{l}\text { Tall trees } \\
\text { Lack of information on use of } \\
\text { chemicals }\end{array}$ & $222(69.2)$ & $99(30.8)$ & $7^{\text {th }}$ \\
& $9(2.8)$ & $312(97.2)$ & $108(33.6)$ \\
\end{tabular}

*Figures in parentheses are percentages

\section{CONCLUSION AND RECOMMENDATIONS}

Citrus production in the Southwest is a popular and rewarding venture, contributing a sizeable proportion of the overall citrus fruits produced in Nigeria. Majority of farmers had favourable attitude towards training in improved techniques of citrus. Topmost production constraints considered limiting are in the order: lack of capital>premature fruit drop >pest incidence>low yielding trees. Citrus farmers who had favourable attitude towards training could be organized for training programmes. There is the need to have farmer sensitization campaigns targeted at farmers who do not have favourable disposition towards training in improved citrus production packages. This will help to boost level of adoption of improved techniques for increased productivity. Integrated pest management techniques should be encouraged among farmers to address pest problems. Existing government initiatives such as agricultural training for 10,000 unemployed youths, NDE, NEEDs, should be further strengthened especially at the Local Government levels which deal directly with the grassroots. Government agencies which disburse loans such as SMEDAN should be encouraged/mandated to set aside special funds for youth empowerment towards citrus production, considering its capital intensive nature.

\section{REFERENCES}

Adegbola A.E. (2008): Consumer behaviour (ENT 2005). Course guide. National Open University $145 \mathrm{pp}$

Adeola, E.O. (1998): Farmers' perception of village extension agents' activities in Ibadan/Ibarapa zone of Oyo State Agricultural Development Programme. An unpublished B.Sc Project of the Department of Agricultural Extension and Rural Development, University of Ibadan, Nigeria. 56pp.

Adetola, A (2008) Ekiti Kete: The value, the virtue and the vision. http://en.wikipedia.org/wiki/Ekiti_State 
Afolayan, S.O, Olaniyan, A.A and Ojo, T.A (2005) The influence of climate on growth and yield performance of twelve sweet orange varieties in Nigeria. In: Proc. of $23^{\text {rd }}$ Annual Conference of Horticultural Society of Nigeria (HORTSON) held at Rivers State College of Education, Port-Harcourt, 18-22 September 2005. p240-243

Aiyelaagbe, I.O.O., A.A. Kintomo, O.M.O. Odeleye, L.O. Ogungbaigbe, K.O. Alasiri, J.A. Adetunji, B. Giginyu, S.O. Afolayan, A. O. Olufolaji, C.A. Amih, V.C. Umeh and J.A. Kolade (1999). "Citrus production in Nigeria : A state of the art". Unpublished Research Monograph No 1. National Horticultural Research Institute. 28pp.

Aiyelaagbe, I.O.O., S.O. Afolayan, O. O. Odeleye, L.O. Ogungbayigbe and A.O. Olufolaji (2001). Citrus production in the savannah of Western Nigeria: Current sstatus and opportunities for research input. Deutsch Tropentag

Ajayi O.A (2006) A study on occupation safety practices among rural farmers in Ile-Ife Area of Osun State, Nigeria: an emphasis on relevant training needs. Res. Journal of Agric.\& Biological Sciences 2(5) 227-235

Akinbile L.A (1999) Item analysis. In: Social science research. Approaches, Techniques and Reporting. Eds.Oladele ,I.O, Akinbile, L. A, Adekoya, A.E. p141

Altmann, M. (1983): Consumer attitudes and market segmentation - The case of the German Flower Market. Acta Horticulture 135:38-389.

Aubert, B and G. Vullin (1998): Citrus nurseries and planting techniques. Center for International Cooperation in Agronomical Research for Development (CIRAD) publication. Acropolis BP 5035, 34032 Montievier Cedex, France. 185pp

Backlund, P (2008) Climate Science Program and the Subcommittee on Global Change Research May 2008. The effect of climate change on agriculture, land resources, water resources, and biodiversity in the United States.

Centre for Rural Development and Training (CRDT) (1993) The identification of training needs. OTTA programme handout. Center for Rural Development and Training University of Wolverhampton Great Britain 2pp.

Economos, C and Clay, W.D (1999) Nutritional and health benefits of citrus fruits. Food, Nutrition and Agriculture 24:11-18.

Emiola, P.O. and O.P. Fawole (2007): Access to Production Information among Citrus farmers in Atisbo Local Government Area of Oyo State. Journal of Agricultural Extension. Vol. 10: 12-19.

FAO (2007) Food and Agricultural Organization of United Nations, Economic and Social Department: The Statistical Division. Wapedia.mobi/en/Citrus_production

Gwary, D (2008) Environmentally friendly pest management in horticultural crop production. In proc. of $26^{\text {th }}$ Annual conference of Horticultural society of Nigeria (HORTSON) held at Adamawa State University, Mubi, Nigeria from October 26-30, 2008. A.A Sajo, K.N. Futuless and Neils, J.Shelleng. p 4-9.

Gwary, D.M. and Nahunnaro, H(2003) Evaluation of tomato cultivars for yields and disease resistance under rainfed conditions in Northern Nigeria. Journal of Arid Agriculture 13:55-63.

International Rice Research Institute (1990): Training and technology transfer course: Performance Objectives Manual (TT1-01).

IPCC(1998) Regional impact of climate. An Assessment of Vulnerability: A special report of IPCC Working Group II. Cambridge University Press.

Ladele, A. A. (1983): A Study of the Training needs of NCE Teachers of Agricultural Science in Secondary Schools in Oyo State. An unpublished M.Sc. Thesis, Department of Agricultural Extension Services. University of Ibadan, Nigeria p 13. 
NARSP (1997) National Agricultural Research Strategy Plan: 1996-2010. B.Shaib, A.Aliyu and J.S.Bakshi (eds) Department of Agricultural Sciences. Federal Ministry of Agriculture, Nigeria.

National Horticultural Research Institute (2000): 25 years of research into horticultural crops development in Nigeria (1975-2000). In: Denton, O.A, K.O. Alasiri and M.A. Adejoro. (eds). $25^{\text {th }}$ Anniversary Commemorative Book. 140pp.

Nigeria: Physical setting- Oyo State (2003) www.onlinenigeria.com/links/oyostate

NIHORT (2008) Horticulture: A panacea for food crisis in Nigeria. Memorandum submitted to senate Ad-Hoc committee on the investigation of Nigeria food crisis and Agricultural Sector 22pp.

Ogungbile, A.O. and J.O. Olukosi (1989) Farming Systems Research Development in Nigeria. In: Proc. Of Appropriate Technologies for Sustainable Agricultural Production in Sub-Saharan Africa held at Ouagadogou, Burkina Faso 11-14 April 1989. Edited by Bezuneh, T. Kamuanga M, Kibreab, T and Olukosi, J. p 29-41.

Ojiambo, J.B. (1992): Information needs for rural development: The case of Malawi. African Journal of Library, Archival and Information Science. Vol.2 No 1 p17-32.

Okigbo, B.N. (1983): Fruits and Vegetables production and extension services in Africa. Acta Horticulturae 123:23-27.

Owoeye, T (2010) Nigeria: Training farmers will boost agricultural production. www.freshplaza.com/news_detail

Umeh, V.C, Garcia, L.E and Meyer, M (2008) Fruit flies of citrus in Nigeria: species diversity, relative abundance and spread in major producing areas. Fruits, vol 3:145153

www.climatescience.gov/Library/sap/sap/4-3/final-report/default.htm

Youdeowei, A, and J. Kwarteng (1995): Development of training materials in agriculture. A course manual of west Africa Rice Development Association 103pp 